\title{
Intrusion of coastal waters into the pelagic eastern Mediterranean: in situ and satellite-based characterization
}

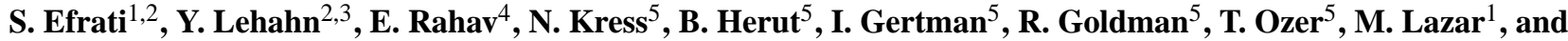 \\ E. Heifetz ${ }^{2,6}$ \\ ${ }^{1}$ The Dr. Moses Strauss Department of Marine Geosciences, University of Haifa, Mt. Carmel 31905, Israel \\ ${ }^{2}$ Department of Geophysics and Planetary Sciences, Tel Aviv University, Ramat Aviv 69978, Israel \\ ${ }^{3}$ Department of Environmental Sciences, Weizmann Institute, Rehovot 76100, Israel \\ ${ }^{4}$ Mina and Everard Goodman Faculty of Life Sciences, Bar-Ilan University, Ramat Gan 52900, Israel \\ ${ }^{5}$ Israel Oceanographic Limnological Research, The National Institute of Oceanography, P.O. Box 8030, Tel Shikmona, \\ Haifa 31080, Israel \\ ${ }^{6}$ Department of Meteorology, Stockholm University, Stockholm, Sweden
}

Correspondence to: Y. Lehahn (yoav.lehahn@weizmann.ac.il)

Received: 22 October 2012 - Published in Biogeosciences Discuss.: 13 December 2012

Revised: 7 March 2013 - Accepted: 23 April 2013 - Published: 21 May 2013

\begin{abstract}
A combined dataset of near-real-time multisatellite observations and in situ measurements from a high-resolution survey is used for characterizing physicalbiogeochemical properties of a patch stretching from the coast to the open sea in the Levantine Basin (LB) of the eastern Mediterranean (EM). Spatial analysis of the combined dataset indicates that the patch is a semi-enclosed system, bounded within the mixed layer and separated from ambient waters by transport barriers induced by horizontal stirring. As such, the patch is characterized by physical-biogeochemical properties that significantly differ from those of the waters surrounding it, with lower salinity and higher temperatures, concentrations of silicic acid and chlorophyll $a$, and abundance of Synechococcus and picoeukaryote cells. Based on estimates of patch dimensions ( $\sim 40 \mathrm{~km}$ width and $\sim 25 \mathrm{~m}$ depth) and propagation speed $\left(\sim 0.09 \mathrm{~m} \mathrm{~s}^{-1}\right)$, the volume flux associated with the patch is found to be on the order of $0.1 \mathrm{~Sv}$. Our observations suggest that horizontal stirring by surface currents is likely to have an important impact on the ultra-oligotrophic Levantine Basin ecosystem, through (1) transport of nutrients and coastally derived material, and (2) formation of local, dynamically isolated niches. In addition, this work provides a satellite-based framework for planning and executing high-resolution sampling strategies in the interface between the coast and the open sea.
\end{abstract}

\section{Introduction}

The eastern Mediterranean (EM) is a semi-enclosed extremely oligotrophic basin. Due to significant evaporation that exceeds runoff and precipitation (POEM group, 1992), the Mediterranean imports from the North Atlantic upper water with low nutrient concentrations and exports nutrients through the mid-depth water outflow (e.g. SiokouFrangou et al., 2010; Krom et al., 2010; Tanaka et al., 2007, 2011). Within the EM, the Levantine Basin (LB) is the most oligotrophic region, with low nutrient and low chlorophyll (LNLC) concentrations, especially during the stratified period (late spring to early autumn) (Berman et al., 1986; Yacobi et al., 1995; Herut et al., 2000; Kress and Herut, 2001). The EM nutrient budget (Krom et al., 2004, 2010) shows significant nutrient inputs, mainly $N$ and $P$, via atmospheric deposition (Herut et al., 1999a, 2002a), while in the northern LB Si inputs are dominated by riverine sources (Koçak et al., 2010).

Despite the basin's ultra-oligotrophic nature, the LB coastal areas are often characterized by relatively high surficial chlorophyll $a$ (Chl) near the coastline, as evident from satellite observations (D'Ortenzio and Ribera d'Alcalà, 2009; Groom et al., 2005). Since chlorophyll is a proxy to phytoplankton biomass, this infers on the higher nutrient concentrations in the coastal waters compared to the open 

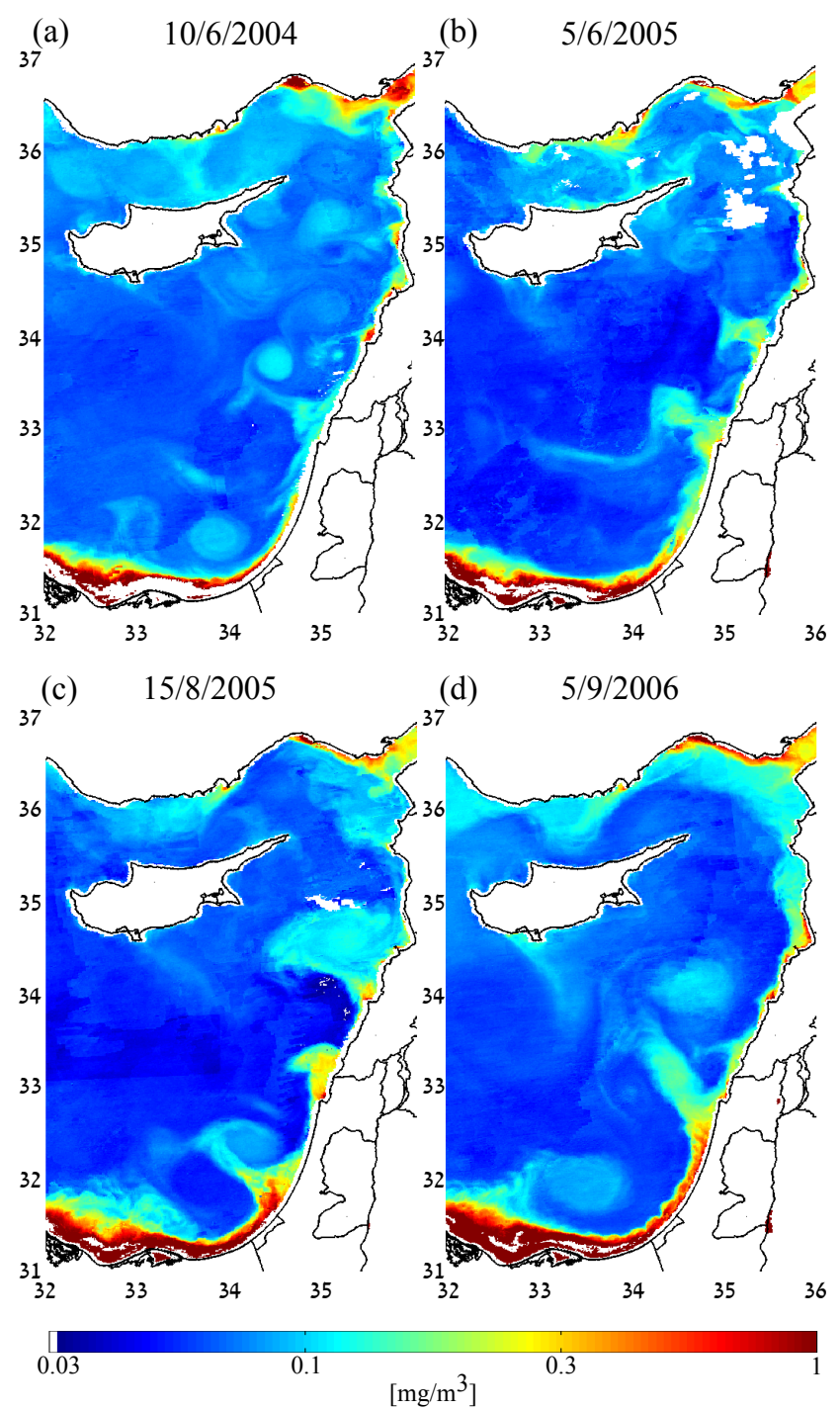

Fig. 1. Distribution patterns of surface chlorophyll $a$ in the Levantine Basin of the eastern Mediterranean, emphasizing the abundance of mesoscale structure extending from the coastal area to the open sea at four different dates. To reduce the area masked by clouds, the images are composed of 8 consecutive days. Throughout the manuscript, surface chlorophyll $a$ and temperature images are derived from MODIS-Aqua $1 \mathrm{~km}$ data.

sea waters. Similar elevated Chl levels at sites along the Israeli coast were also recorded by hyper-spectral remote sensing surveys (Herut et al., 1999b, 2002b). Intrusion of these nutrient-enriched coastal waters into the open sea often stimulates local plankton blooms that take the form of distinct mesoscale $(\sim 10-\sim 100 \mathrm{~km})$ Chl patches stretching from the coast to the open sea for periods of days to months (Barale et al., 2008). The persistence of these widely spread intrusion structures (Fig. 1) suggests that they have an important impact on the pelagic LB ecosystem.
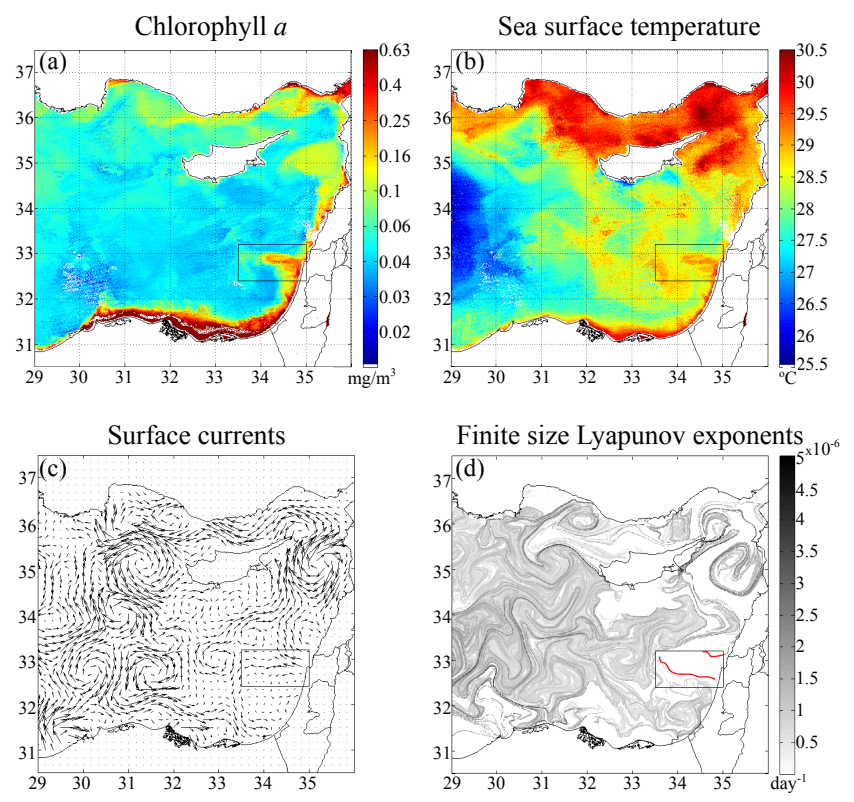

Fig. 2. Satellite-derived maps of the Levantine Basin of the Eastern Mediterranean (a) chlorophyll $a$ concentrations, (b) sea surface temperature, (c) surface currents and (d) finite size Lyapunov exponents, from 22 August 2011. The boxes mark the area shown in Fig. 3. The red lines in panel d highlight the unstable manifolds constraining the patch from the north and from the south (see text).

Formation of mesoscale Chl patterns often results from horizontal stirring (Martin, 2003) that may be generated by meandering of the surface alongshore currents (Gertman et al., 2010). As recently shown, transport barriers induced by the stirring may control the spatial distribution of phytoplankton, through the formation of dynamical boundaries that prevent mixing between water bodies with different physical and biogeochemical characteristics (Lehahn et al., 2007; Huhn et al., 2012). Multi-satellite observations show that such dynamical boundaries may separate between ecological niches that are dominated by different phytoplankton types (d'Ovidio et al., 2010), and can form quasi-isolated planktonic systems that are separated from their surroundings for several months (Lehahn et al., 2011). In addition, it was shown that dynamical boundaries may form barriers and trap passive scalars even at small scales of $\sim 1-10 \mathrm{~km}$ (Gildor et al., 2009) . This suggests that the coast-to-open-sea intrusions observed in the LB represent not only transport of coastal waters with their unique characteristics, but also isolated systems that are separated from ambient waters by transport barriers associated with the surface velocity field.

The current study is aimed at characterizing and estimating the possible environmental impacts of coast-to-open-sea intrusions on the pelagic water of the LB. We focus on an individual intrusion event that took the form of a distinct Chl patch stretching from the Mediterranean coast of Israel to the open sea (Fig. 2a). This event represents similar 
long-term ongoing events observed along the coast of Israel and other EM coasts (Fig. 1). We characterized the patch's physical, chemical and biological properties, in comparison to the properties of the waters surrounding it. The strategy for the research was as follows. First, the patch and its transport barriers were identified from analysis of near-real-time satellite data. Then a high-resolution field campaign, covering the area of the patch and its vicinity, was launched. The sampling strategy for the campaign was planned and implemented based on satellite-based estimates of the patch extension, and on continuous on-board measurements of surface temperature and fluorescence.

\section{Data and methods}

\subsection{Satellite data}

Surface currents were obtained from the AVISO database (http://www.aviso.oceanobs.com). During the period examined in this study, the distributed global product was a combination of altimetric data from Jason-1 and -2 and Envisat missions. The dataset was comprised of daily near-real-time sea-level-anomaly data files, gridded on a $1 / 8^{\circ} \times 1 / 8^{\circ}$ Mercator grid. This product also included the mean dynamic topography field RioMed (Rio et al., 2007). The use of satellite altimetry in the area close to the coast is difficult and may lead to errors in the calculated velocity field. Major obstacles are land contamination of the radar altimeter measurements, and the difficulty to accurately correct the effect of environmental factors such as tides and atmospheric conditions. The altimetry dataset does not include measurements at distances of less than $\sim 10 \mathrm{~km}$ from the coastline.

Transport barriers between fluid domains were delimited by identifying attracting Lagrangian coherent structures (LCSs; Haller and Yuan, 2000) in the satellite-derived surface velocity field. In recent years, novel approaches for locating material transport barriers in two-dimensional flows were introduced (Haller 2011; Haller and Beron-Vera 2012). Here, the barriers are identified as ridges of local maxima in the field of finite size Lyapunov exponents (FSLE) (Boffetta et al., 2001). This method has been shown to be efficient in detecting transport barriers that delimit the spatial distribution of oceanic tracers such as surface chlorophyll and temperature (d'Ovidio et al., 2004, 2010; Lehahn et al., 2007).

Surface Chl and sea surface temperature (SST) were derived from the Moderate Resolution Imaging Spectroradiometer (MODIS) aboard Aqua. The dataset was comprised of $1 \mathrm{~km}$ images, obtained from the ocean color data distribution site (http://oceandata.sci.gsfc.nasa.gov/). Satellite retrieval of $\mathrm{Chl}$ in the Mediterrenean Sea are often overestimated, among other reasons due to the presence of suspended Saharan dust and coccolithophores in the water column (Claustre et al., 2002; d'Ortenzio et al., 2002). Furthermore, since the study area is close to and influenced by the
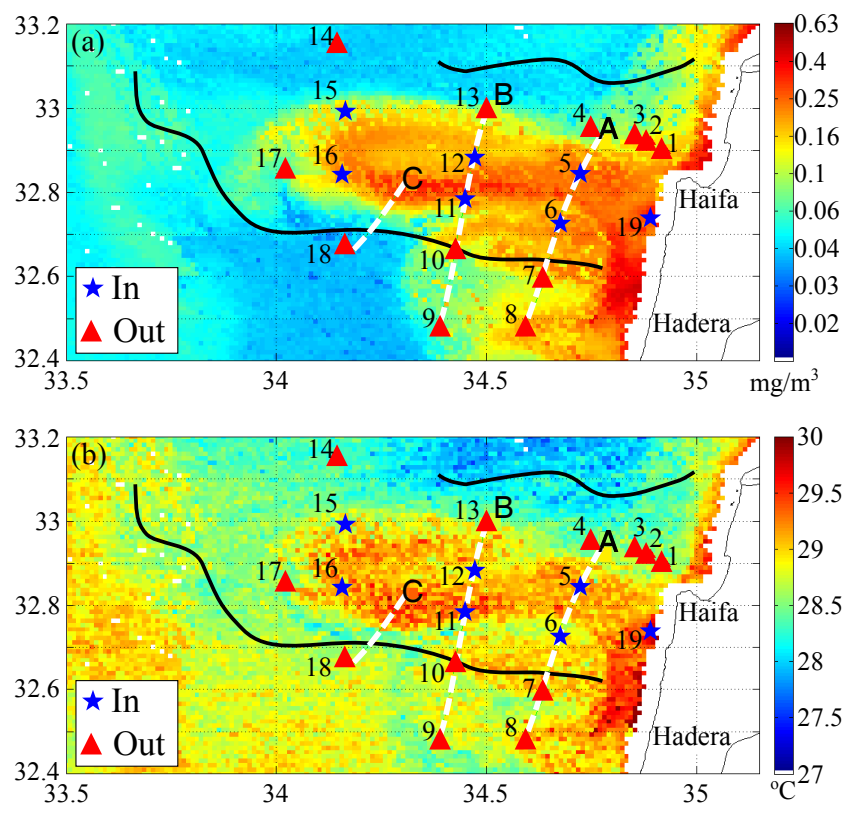

Fig. 3. Sea surface (a) chlorophyll $a$ and (b) temperature associated with the intrusive patch observed on 22 August 2011. Solid black lines mark the attracting LCSs constraining the patch from the north and from the south. Dashed white lines mark the sections presented in Fig. 4. The letters A, B and C denote the sections delimited in Fig. $4 \mathrm{a}-\mathrm{c}$, respectively. Blue stars and red triangles represent the locations of sampling stations in and out of the patch, respectively (location of the stations with respect to the patch is defined according the sections in Fig. 4). Numbers denote station names.

coastal zone, the waters can be considered as case 2, where optical properties are mostly influenced by mineral particles or colored dissolved organic matter (Morel and Prieur, 1977). As in Bignami et al. (2007), we thus point to the limitations of the term "chlorophyll" as used in this paper, and note that there may be differences between the satellite retrievals data and in situ values.

\subsection{In situ measurements}

The cruise was conducted aboard the R/V Shikmona on 2224 August 2011, when the patch was distinctly evident in satellite images of sea surface chlorophyll (Fig. 2a). We sampled 19 stations that represent the conditions in and out of the patch (Fig. 3; the criterion for defining stations in and out of the patch is described in Sect. 3). In each station continuous profiles of pressure, temperature, salinity, dissolved oxygen, and fluorescence were measured using the Sea-Bird SBE 911 plus CTD system, interfaced to a SBE Carousel equipped with twelve $8 \mathrm{~L}$ Niskin bottles. In addition, at 13 stations, water samples for the determination of nutrients, $\mathrm{Chl}$ and picophytoplankton were collected using Niskin bottles at four sampling depths: two at the upper mixed layer (surface and base of the mixed layer), one at the minimum salinity layer $\left(\operatorname{Min}_{\text {Sal }}\right)$, and one at the deep chlorophyll maximum (DCM). 
In addition, continuous measurements of temperature, salinity and Chl fluorescence of surface waters were performed along the cruise track using an additional CTD and a flowthrough system.

Duplicate water samples for the determination of nutrients were collected in $15 \mathrm{~mL}$ acid-washed plastic scintillation vials and were immediately frozen. Nutrients were determined in the laboratory using a segmented flow Seal Analytical AA-3 system by the methods described by Krom et al. (1991) and Kress and Herut (2001). The precision of the nitrate+nitrite, orthophosphate and silicic acid measurements were $0.02,0.003$ and $0.06 \mu \mathrm{M}$, respectively. The limits of detection were $0.08 \mu \mathrm{M}, 0.008 \mu \mathrm{M}$ and $0.03 \mu \mathrm{M}$ for nitrate + nitrite, orthophosphate and silicic acid, respectively. The concentrations reported are the average values. Samples of $1.8 \mathrm{~cm}^{3}$ for picophytoplankton enumeration were fixed immediately upon collection with $20 \mu \mathrm{L}$ of $25 \%$ glutaraldehyde, retained at room temperature for $10 \mathrm{~min}$, frozen in liquid nitrogen and stored at $-80^{\circ} \mathrm{C}$ until analysis within 2 months from collection. Before analysis in the laboratory, samples were fast-thawed at $37^{\circ} \mathrm{C}$ and excited in a flow cytometer - FACScan Becton Dickinson - fitted with an Argon laser $(488 \mathrm{~nm})$ for 10 to $15 \mathrm{~min}$, or until 30000 cells were counted (Marie et al., 2005). Taxonomic discrimination was based on the following: cell side scatter - a proxy of cell volume; forward scatter - a proxy of cell size; and orange and red fluorescence of phycoerythrin and of Chl $(585 \mathrm{~nm}$ and $630 \mathrm{~nm}$, respectively). Samples for Chl determination were filtered through GF/F filters that were folded, wrapped in aluminum paper and frozen. Chl was measured fluorometrically following extraction with $95 \%$ acetone (Holm-Hansen et al., 1965). The results were used to calibrate the CTD fluorescence profiles.

\section{Results and discussion}

The intrusive patch characterized in this work is distinctly identified as a positive Chl concentration anomaly (Fig. 2a). The patch boundaries are delimited by the location of the $\mathrm{Chl}$ front, which separates the area of high $\mathrm{Chl}$ associated with the patch from its low-Chl surroundings. On average, satellite-derived $\mathrm{Chl}$ concentrations are $0.16 \pm 0.08 \mathrm{mg} \mathrm{m}^{-3}$ (mean and standard deviation, respectively; unless stated otherwise, the same notation is used hereafter) within the patch, and $0.06 \pm 0.03 \mathrm{mg} \mathrm{m}^{-3}$ in the surrounding waters. The patch, which extends from the eastern coastline towards the open sea, covers an overall area of approximately $4000 \mathrm{~km}^{2}$ ( $\sim 100 \mathrm{~km}$ in length and $\sim 40 \mathrm{~km}$ in width). The lifetime of the patch, deduced from analyzing a sequence of Chl concentration maps (not shown), is about 45 days (from 30 July to 12 September), a period during which its shape and size vary. The $\mathrm{Chl}$ patch overlaps a similar structure of warmer waters (average satellite-derived temperature of $28.6 \pm 0.4{ }^{\circ} \mathrm{C}$ within the patch vs. $28.2 \pm 0.2^{\circ} \mathrm{C}$ in the surrounding waters) in the sea surface temperature field (Fig. 2b).

These patch characteristics are similar to the relatively high $\mathrm{Chl}$ and SST in the nearby coastal region. This spatial continuity in high $\mathrm{Chl}$ and SST levels suggests that the waters in the patch originate in the coastal area. This hypothesis is strongly supported by the westward direction of surface currents associated with the patch (Fig. 2c). Further examination of the surface currents' impact on the properties of the patch was carried out by detecting transport barriers through identification of attracting LCSs from the satellitederived velocity field (Fig. 2d). More specifically, we focused on the attracting LCSs adjacent to the patch (red and black lines in Figs. 2d and 3, respectively). In accordance with the hypothesis of the patch resulting from westward advection of coastal waters, the adjacent attracting LCS forms a dynamical "corridor" delimiting the patch from the north and from the south. The southern edge of the patch remarkably coincides with the adjacent attracting LCS (Fig. 2d), suggesting the latter acts as a dynamic patch boundary (DPB) that separates between the patch and the waters south of it. The closest attracting LCS to the north is found approximately $20 \mathrm{~km}$ to the patch's northern edge. This discrepancy can be attributed to insufficient resolution (in space and time) of the satellite altimetry data.

The ability of attracting LCSs to delimit transport barriers that shape and separate marine systems with distinct physical-biogeochemical properties was recently shown in a number of studies (Lehahn et al., 2007; d'Ovidio et al., 2010; Huhn et al., 2012). Here, this ability is tested through continuous in situ measurements of temperature and fluorescence at three sections across the DPB, which is delimited by the unstable manifold adjacent to the patch's southern edge (Fig. 4). In agreement with the notion of unstable manifolds bounding marine systems, the crossing of the DPB (black squares in Fig. 4) is associated with strong fronts in temperature and fluorescence, with both fields going from background (i.e. outside the patch) levels to maximum patch levels over short distances of less than $5 \mathrm{~km}$.

The surface properties of the water body associated with the patch (derived from the satellite and continuous in situ datasets), strongly suggest that it can be considered as a dynamically isolated or quasi-isolated system (Lehahn et al., 2011), whose physical, chemical and biological properties are significantly different from those of its surroundings. This view of the patch is further examined by comparing a series of depth profiles in stations in and out of the patch (Fig. 5). The location of the stations (with respect to the patch) was defined objectively according to the location of the fronts in surface fluorescence and temperature (blue stars and red triangles in Fig. 4, for stations in and out of the patch, respectively).

In agreement with previous late summer measurements (D'Ortenzio et al., 2005), the water column is well stratified, with a distinct mixed layer reaching a depth of approximately 

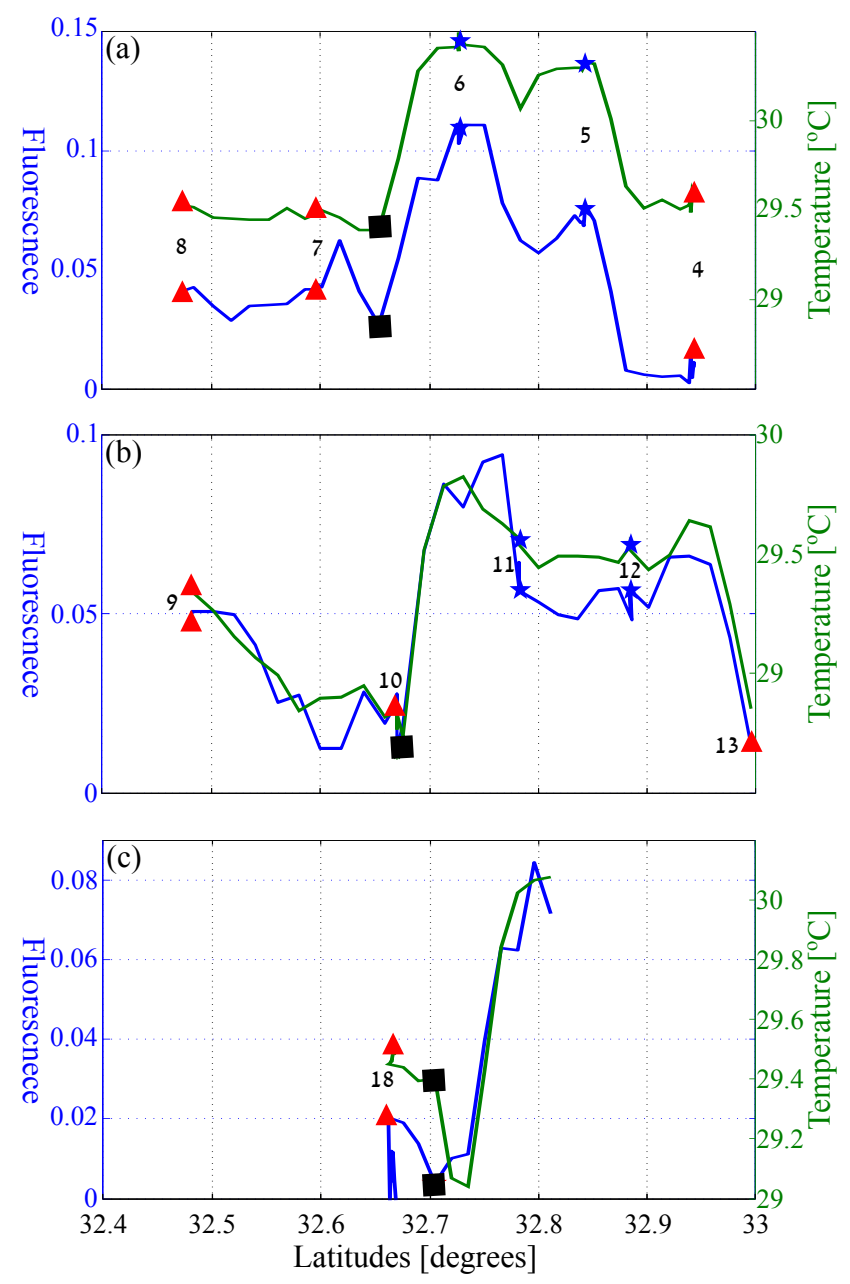

Fig. 4. In situ measured surface temperature (green) and fluorescence (blue, arbitrary unit) along three meridional sections orthogonal to the patch's main axis (dashed white lines and corresponding letters in Fig. 3). Blue stars and red triangles mark the locations of sampling stations in and out of the patch, respectively. Numbers denote station names. The black square marks intersection with the southern dynamic patch boundary (DPB), associated with the attracting LCS adjacent to the patch's southern edge. Note the change in scale between the different panels.

$25 \mathrm{~m}$ (Fig. 5a). Within the mixed layer, water associated with the patch (blue points in Fig. 5) is less dense (24.75$\left.25.5 \mathrm{~kg} \mathrm{~m}^{-3}\right)$, less saline (38.9-39.2) and warmer $\left(29-30^{\circ} \mathrm{C}\right)$ than that outside the patch $\left(25.5 \mathrm{~kg} \mathrm{~m}^{-3}, 38.9-39.4\right.$ and $28-$ $29^{\circ} \mathrm{C}$, respectively; red points in Fig. 5). For greater depths, water density, salinity and temperature do not exhibit significant differences between waters in and out of the patch. Hence, we deduce that the patch corresponds to a distinct water body whose physical properties differ significantly from those of ambient waters, and which is associated with isolated horizontal transport through the $\sim 25 \mathrm{~m}$ mixed layer. The low-salinity water within the patch most likely originates from a local coastal upwelling due to alongshore
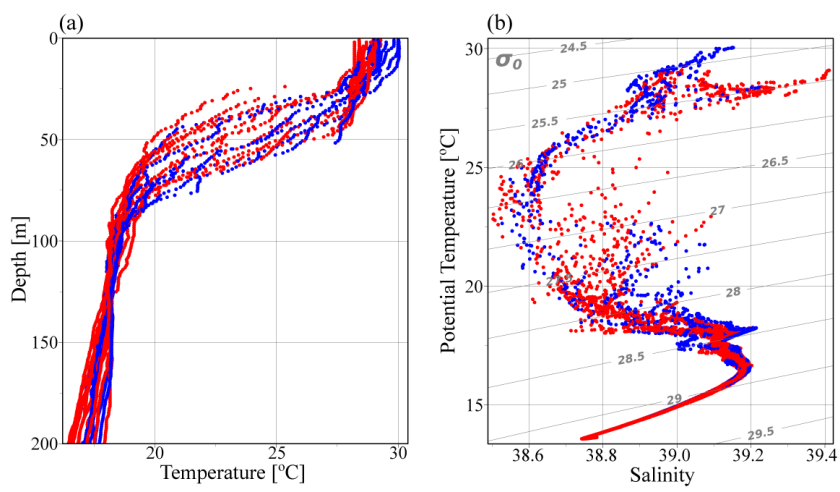

Fig. 5. (a) Vertical profiles of temperature and (b) T-S diagram, for stations in (blue) and out (red) of the patch (see Fig. 3 for station locations). Figure was made using Ocean Data View (Schlitzer, 2011).

current meander. At the surface the water warms quickly due to high salinity stratification inside the patch. Based on previous works, we estimate that the local upwelling occurred in the vicinity of Haifa Bay (northeast of the patch), where circulation is disturbed by the complicate topography (Rosentraub and Brenner, 2007).

Further elucidation of the link between the patch properties and horizontal transport by surface currents was obtained by the extraction of satellite-derived $\mathrm{Chl}$ time series over 4 regions of interest (ROIs) located at equal distances $\left(0.2^{\circ}\right)$ along the patch's main axis (Fig. 6a). For all 4 ROIs, Chl evolution is characterized by a distinct increase in surface chlorophyll concentrations (Fig. 6b). The timing of Chl increase varies between the 4 ROIs, starting near the coast (ROI A) and gradually advancing as the distance from the coast increases. Following the assumption that the patch is driven by horizontal transport of productive coastal waters, the differences in timing (of Chl increase) can be interpreted as the time required for the patch to cover the distances between the ROIs, thus providing a measure to the patch propagation speed. Dividing the distance between the ROIs and timing of chlorophyll increase provides an estimated propagation velocity of approximately $7.4 \mathrm{~km} \mathrm{day}^{-1}\left(\sim 0.09 \mathrm{~m} \mathrm{~s}^{-1}\right)$, which is in agreement with the velocity of the surface currents $\left(\sim 0.1 \mathrm{~m} \mathrm{~s}^{-1}\right)$. Considering the above-described patch dimensions ( $\sim 40 \mathrm{~km}$ width and $\sim 25 \mathrm{~m}$ depth) and propagation speed, we estimate the outflow volume of coastal water associated with the patch (and responsible for its formation) to be on the order of $\sim 0.1 \mathrm{~Sv}$. Though representing a transient short-term $(\sim 10$ days $)$ event, this is a remarkable volume flux of water, which is comparable to main EM water pathways, such as the mean outflow from the Aegean Sea (e.g. averages of $0.4 \mathrm{~Sv}$ for the years 1987-1994 (Nittis et al., 2003) and 0.7 Sv for the years 1988-1993 (Rupolo et al., 2003)). 

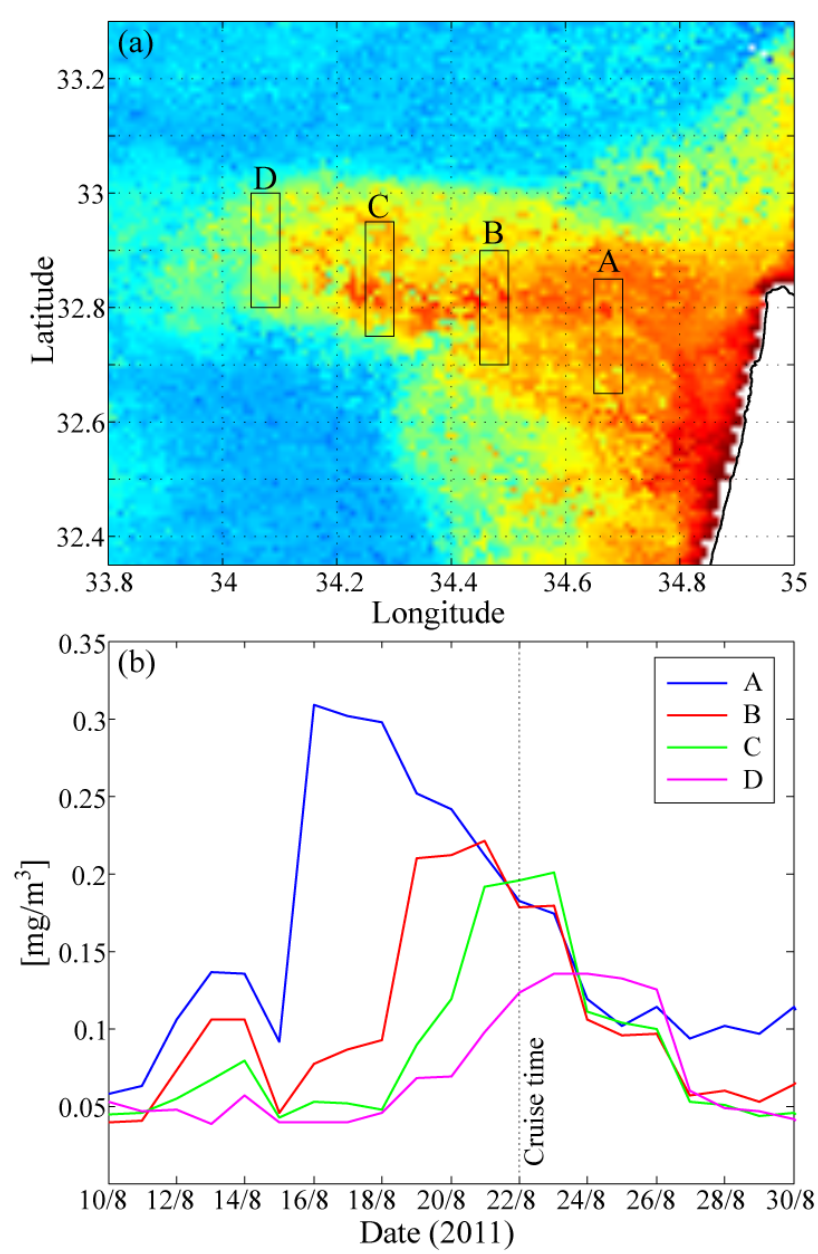

Fig. 6. (a) Black boxes mark the locations of regions of interest (ROIs) along the patch's main axes, used for extracting the time series in panel (b). The ROIs are superimposed on a satellite-derived chlorophyll map showing the patch's extension. (b) Temporal evolution of surface chlorophyll concentrations at the 4 regions of interest along the patch's main axis.

The patch is also characterized by a distinct biogeochemical signature. A significant inorganic chemical indicator is silicic acid $\left(\mathrm{Si}(\mathrm{OH})_{4}\right)$ (Fig. $\left.7 \mathrm{a}, \mathrm{b}\right) . \mathrm{Si}(\mathrm{OH})_{4}$ concentrations within the patch are higher by $22-35 \%$ than outside of it at the surface and at the mixed-layer depth (MLD). Inside the patch, $\mathrm{Si}(\mathrm{OH})_{4}$ ranged from 1.3 to $2.2 \mu$ mole $\mathrm{kg}^{-1}$ at the surface, and 0.8 to $1.6 \mu$ mole $\mathrm{kg}^{-1}$ at the MLD. The linear relationship $\left(P<0.05, R^{2}=0.5\right)$ between $\mathrm{Si}(\mathrm{OH})_{4}$ concentrations and temperature for surface water represents a conservative behavior of mixing between two end-members, shallow coastal waters, warm and enriched with $\mathrm{Si}(\mathrm{OH})_{4}$, and open sea pelagic water, colder with lower levels of $\mathrm{Si}(\mathrm{OH}) 4$ (Fig. 8a). No similar signal is identified for $\mathrm{NO}_{3}+\mathrm{NO} 2$ nor for $\mathrm{PO}_{4}$, whose concentrations were low and similar at all stations $\left(0.5-1.0 \mu\right.$ mole $\mathrm{kg}^{-1}$ and close to the detection limit $\left(0.007 \mu\right.$ mole $\left.\mathrm{kg}^{-1}\right)$, respectively). As previously

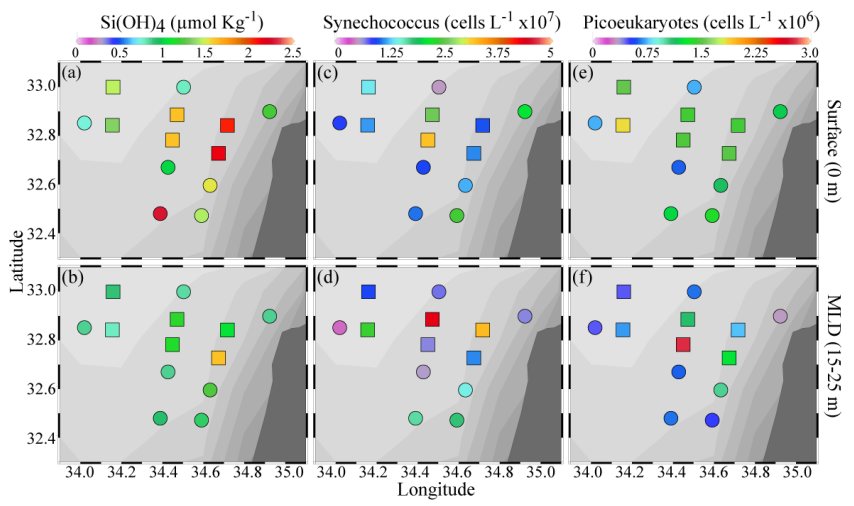

Fig. 7. Spatial distribution of (a), (b) $\mathrm{Si}(\mathrm{OH})_{4}$ concentrations; (c), (d) Synechococcus and (e), (f) picoeukaryote abundance at the surface (upper panels) and mixed-layer depth (lower panels). Squares and circles mark stations located in and out of the patch, respectively (see Fig. 3 for station numbers). Figure was made using Ocean Data View (Schlitzer, 2011).
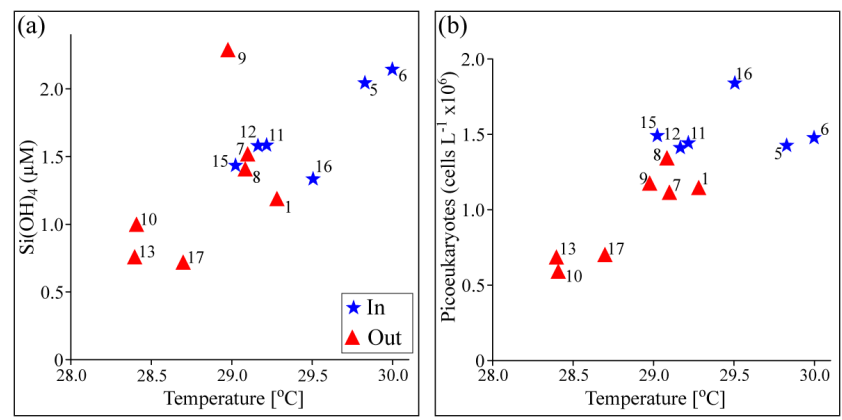

Fig. 8. Relationships between temperature and (a) dissolved silicic acid $\left(\mathrm{Si}(\mathrm{OH})_{4}\right)$ concentrations, and (b) abundance of picoeukaryote cells at surface waters from stations in and out of the patch.

shown, a possible source for the high levels of silicic acid is discharge of nutrient-enriched freshwaters from springs (Weinstein et al., 2006).

Abundance of Synechococcus cells at the surface was 2fold higher inside the patch than outside of it, with maximal abundances at stations 11 and $12\left(3.2 \times 10^{7}\right.$ and $2.5 \times 10^{7}$ cells $\mathrm{L}^{-1}$, respectively) (Fig. 7c, d). At the stations out of the patch, Synechococcus abundance was low, ranging from $4.9 \times 10^{6}$ to $1.2 \times 10^{7}$ cells $\mathrm{L}^{-1}$, except for surface water of the coastal stations 1 and 8 where high abundances were observed $\left(2.8 \times 10^{7}\right.$ and $2.4 \times 10^{7}$ cells $\mathrm{L}^{-1}$, respectively). The vertical trend in Synechococcus abundance remained the same with $>2$-fold increase in average cell number at the stations in rather than out of the patch. Picoeukaryote abundance was higher at the patch stations compared to the surroundings by $1.5-2.3$ times throughout all depths sampled (Fig. 7e, f). This enrichment was also reflected in the significant linear relationship $\left(P<0.05, R^{2}=0.62\right)$ between picoeukaryote abundance and temperature at the 
surface and MLD samples (Fig. 8b). Inside the patch, surface picoeukaryote abundance is relatively constant $\left(\sim 1.4 \times 10^{6}\right.$ cells $\mathrm{L}^{-1}$ ), increasing toward the MLD (station $11,2.8 \times 10^{6}$ cells L $\left.{ }^{-1}\right)$ and $\mathrm{Min}_{\mathrm{Sal}}\left(2.7 \times 10^{6}\right.$ cells $\left.\mathrm{L}^{-1}\right)$. Prochlorococcus abundance did not show any significant spatial trend, with values ranging from $1.5 \times 10^{7}$ to $1.8 \times 10^{7}$ cells $\mathrm{L}^{-1}$ and $3 \times 10^{6}$ to $1 \times 10^{7}$ cells $\mathrm{L}^{-1}$ for stations located in and out of the patch, respectively (not shown). This is explained by the fact that in the Mediterranean Prochlorococcus are usually associated with deep chlorophyll maximum (lowlight species, $\sim 100 \mathrm{~m}$ ), and are thus not affected by the intrusion of waters at the upper $25 \mathrm{~m}$ of the water column. It is reasonable to assume that the higher abundance of Synechococcus and picoeukaryotes inside the patch was a result of available nitrate and phosphate supplied from the near shore. Their utilization decreased the concentrations in seawater and masked any differences between the waters in and out of the patch. We note that heterotrophic bacteria could also consume inorganic $\mathrm{N}$ and $\mathrm{P}$ but were not measured during this study. The relatively high $\mathrm{Si}(\mathrm{OH})_{4}$ concentration found inside the patch suggests that most of the $\mathrm{Si}(\mathrm{OH})_{4}$ was not utilized and remained in the seawater.

\section{Summary and conclusions}

In this work we integrated near-real-time multi-satellite datasets and in situ measurements from a high-resolution survey, to characterize physical-biogeochemical properties of a patch stretching from the coast to the open sea, in the Levantine Basin of the eastern Mediterranean. Based on Lagrangian analysis of satellite-derived velocity field, and comparison with spatial variations of in situ measured physical and biogeochemical properties, the patch is identified as a semi-enclosed system that is bounded within a $\sim 25 \mathrm{~m}$ mixed layer and is separated from ambient waters by transport barriers induced by the surface currents. The separation between the patch and its surroundings is expressed by significant differences in a number of physical (the patch is less saline and warmer) and biogeochemical (the patch is richer in silicic acid and chlorophyll, and is more abundant in Synechococcus and picoeukaryote cells) parameters. The anomalous values associated with the patch can originate both in local upwelling that introduces waters from below the seasonal thermocline, and in coastal waters that are influenced by terrestrial sources such as rivers and submarine groundwater discharges.

These results suggest that horizontal stirring is likely to have an important impact on the ultra-oligotrophic Levantine Basin ecosystem, through two main scenarios:

1. Transport of nutrients and coastally derived material from the near-shore area to the open sea. Its potential importance is emphasized by the fact that the patch is associated with a remarkable westward volume flux ( $\sim 0.1 \mathrm{~Sv}$ ), and by the fact that similar structures ap- pear regularly at different locations around the basin's periphery. Furthermore, since coastal environments are globally highly productive areas (Chavez and Smith, 1995), the suggested impact of horizontal stirring is likely to be important at the coast-open sea interface around the globe, especially at oligotrophic areas.

2. Formation of localized niches that are separated from their surrounding by transport barriers, and are thus subject to different dynamics. As recently shown by d'Ovidio et al. (2010), such fluid dynamical niches may sustain different planktonic communities, and can play a key role in the dynamics and maintenance of planktonic biodiversity in the interface between the coastal area and the open sea.

Finally, we note that the accurate detection of transport barriers from near-real-time satellite altimetry data, together with the proven ability to plan and execute a high-resolution sampling strategy, provide a promising framework for efficient rapid response in cases of pollution events in the interface between the coast and the open sea.

Acknowledgements. This research was funded by the Israeli Ministry of Science and Technology (MOST 3-6490). The authors acknowledge NASA access to MODIS-Aqua data. The altimeter products were produced by Ssalto/Duacs and distributed by Aviso with support from the Centre National d'Études Spatiales. We are grateful to the crew of the R/V Shikmona and the research assistants of the Marine Chemistry Department at IOLR for their help at sea and in the laboratory. Eyal Heifetz is grateful for the Rossby Visiting Fellowship of the International Meteorological Institute (IMI) of Sweden. All figures in this paper received their final touch by using Inkscape, an open source vector graphics editor.

Edited by: A. Bricaud

\section{References}

Barale, V., Jaquet, J.-M., and Ndiaye, M.: Algal blooming patterns and anomalies in the Mediterranean Sea as derived from the SeaWiFS data set, Remote Sens. Environ., 112, 3300-3313, 2008.

Berman, T., Azov, Y., Schneller, A., Walline, P., and Townsend, D. W.: Extent, transparency, and phytoplankton distribution of the neritic waters overlying the Israeli coastal shelf, Oceanol. Acta, 9, 439-447, 1986.

Bignami, F., Sciarra, R., Carniel, S. and Santoleri, R.: Variability of Adriatic Sea coastal turbid waters from SeaWiFS imagery, J. Geophys. Res.-Oc., 112, C03S10, doi:10.1029/2006JC003518, 2007.

Boffetta, G., Lacorata, G., Redaelli, G., and Vulpiani, a.: Detecting barriers to transport: a review of different techniques, Physica D, 159, 58-70, 2001.

Chavez, F. and Smith, S.: Biological and chemical consequences of open ocean upwelling, in: Upwelling in the Oceans Modern Processes and Ancient Records, edited by: Summerhayes, C. P., 
Emeis, K. C., Angel, M. V., Smith, R. L., and Zeitschel, B., Wiley, Chichester, 147-170, 1995.

Claustre, H., Morel, A., Hooker, S. B., Babin, M., Antoine, D., Oubelkheir, K., Bricaud, A., Leblanc, K., Quéguiner, B., and Maritorena, S.: Is desert dust making oligotrophic waters greener?, Geophys. Res. Lett., 29, 107-1-107-4, doi:10.1029/2001GL014056, 2002.

D’Ortenzio, F., Marullo, S., Ragni, M., Ribera d'Alcalá, M., and Santoleri, R.: Validation of empirical SeaWiFS algorithms for chlorophyll- $\alpha$ retrieval in the Mediterranean Sea, A case study for oligotrophic seas, Remote Sens. Environ., 82, 79-94, 2002.

D’Ortenzio, F., Iudicone, D., De Boyer Montegut, C., Testor, P., Antoine, D., Marullo, S., Santoleri, R., and Madec, G.: Seasonal variability of the mixed layer depth in the Mediterranean Sea as derived from in situ profiles, Geophys. Res. Lett., 32, 2-5, 2005.

D'Ortenzio, F. and Ribera d'Alcalà, M.: On the trophic regimes of the Mediterranean Sea: a satellite analysis, Biogeosciences, 6, 139-148, doi:10.5194/bg-6-139-2009, 2009.

d'Ovidio, F., Fernández, V., Hernández-García, E., and López, C.: Mixing structures in the Mediterranean Sea from finite-size Lyapunov exponents, Geophys. Res. Lett., 31, 1-7, 2004.

d'Ovidio, F., De Monte, S., Alvain, S., Dandonneau, Y., and Lévy, M.: Fluid dynamical niches of phytoplankton types., Proc. Nat. Acad. Sci., 107, 18,366-70, doi:10.1073/pnas.1004620107, 2010 .

Gertman, I., Goldman, R., Rosentraub, Z., Ozer, T., Zodiatis, G., Hayes, D., and Poulain, P.-M.: Generation of Shikmona anticyclonic eddy from an alongshore current, Rapp. Comm. int. Mer Medit. (CIESM Congress Proceedings), 39, 114, 2010.

Gildor, H., Fredj, E., Steinbuck, J., and Monismith, S.: Evidence for submesoscale barriers to horizontal mixing in the ocean from current measurements and aerial-photographs, J. Phys. Oceanogr., 39, 1975-1983, doi:10.1175/2009JPO4116.1, 2009.

Groom, S., Herut, B., Brenner, S., Zodiatis, G., Psarra, S., Kress, N., Krom, M. D., Law, C. S., and Drakopoulos, P.: Satellite-derived spatial and temporal biological variability in the Cyprus Eddy, Deep-Sea Res., 52, 2990-3010, 2005.

Haller, G. A: variational theory of hyperbolic Lagrangian Coherent Structures, Physica D, 240, 574-598, 2011.

Haller, G. and Beron-Vera, F. J.: Geodesic theory of transport barriers in two-dimensional flows, Physica D, 241, 1680-1702, 2012.

Haller, G. A. and Yuan, G.: Lagrangian coherent structures and mixing in two-dimensional turbulence, Physica D, 147, 352-370, doi:10.1016/S0167-2789(00)00142-1, 2000.

Herut, B., Krom, M., Pan, G., and Mortimer, R.: Atmospheric input of nitrogen and phosphorus to the se Mediterranean: sources, fluxes and possible impact, Limnol. Oceanogr., 44, 1683-1692, 1999a.

Herut, B., Tibor, G., Yacobi, Y. Z., and Kress, N.: Synoptic measurements of chlorophyll $a$ and suspended particulate matter in a transitional zone from polluted to clean seawater utilizing airborne remote sensing and ground measurements, Haifa bay (se Mediterranean), Mar. Poll. Bull., 38, 762-772, 1999 b.

Herut, B., Almogi-Labin, A., Jannink, N., and Gertmann, I.: seasonal dynamics of nutrient and chlorophyll $a$ concentrations on the se mediterranean shelf-slope, Oceanol. Acta, 23, 771-782, 2000.

Herut, B., Collier, R., and Krom, M. D.: The role of dust in supplying $\mathrm{n}$ and $\mathrm{p}$ to the se Mediterranean, Limnol. Oceanogr., 47,
870-878, 2002a.

Herut, B., Kress, N., and Tibor, G.: The use of hyper-spectral remote sensing in compliance monitoring of water quality (phytoplankton and suspended particles) at "hot spot" areas (Mediterranean coast of Israel), Fresenius Environ. Bull., 11, 782-787, 2002b.

Holm-Hansen, O., Lorenzen, C. J., Holmes, R. W., and Strickland, J. D. H.: Fluorometric determination of chlorophyll, Journal du Conseil, Permanent International pour l'Exploration de la Mer, 30 pp., 1965.

Huhn, F., von Kameke, A., Perez-Munuzuri, V., Olascoaga, M. J., and BeronVera, F. J.: The impact of advective transport by the south Indian Ocean countercurrent on the madagascar plankton bloom, Geophys, Res. Lett., 39, L06602, doi:10.1029/2012GL051246, 2012.

Koçak, M., Kubilay, N., Tuğrul, S., and Mihalopoulos, N.: Atmospheric nutrient inputs to the northern levantine basin from a long-term observation: sources and comparison with riverine inputs, Biogeosciences, 7, 4037-4050, doi:10.5194/bg-7-40372010, 2010.

Kress, N. and Herut, B.: Spatial and seasonal evolution of dissolved oxygen and nutrients in the Southern Levantine Basin (Eastern Mediterranean Sea): chemical characterization of the water masses and inferences on the N : P ratios, Deep-Sea Res., 48, 2347-2372, 2001.

Krom, M. D., Brenner, S., Kress, N., and Gordon, L.: Phosphorus limitation of primary productivity in the eastern mediterranean sea, Limnol. Oceanogr., 36, 424-432, 1991.

Krom, M. D., Herut, B., and Mantoura, R. F. C.: Nutrient budget for the Eastern Mediterranean: Implications for phosphorus limitation, Limnol. Oceanog., 49, 1582-1592, 2004.

Krom, M. D., Emeis, K.-C., and Van Cappellen, P.: Why is the Eastern Mediterranean phosphorus limited?, Prog. Oceanog., 85, 236-244, 2010.

Lehahn, Y., d'Ovidio, F., Lévy, M., and Heifetz, E.: Stirring of the northeast Atlantic spring bloom: A Lagrangian analysis based on multisatellite data, J. Geophys. Res., 112, C08005, doi:10.1029/2006JC003927, 2007.

Lehahn, Y., d'Ovidio, F., Lévy, M., Amitai, Y., and Heifetz, E.: Long range transport of a quasi isolated chlorophyll patch by an Agulhas ring, Geophys. Res. Lett., 38, 1-6, 2011.

Morel, A. and Prieur, L.: Analysis of variations in ocean color, Limnol. Oceanogr., 22, 709-722, 1977.

Marie, D., Simon, N., and Vaulot, D.: Phytoplankton cell counting by flow cytometry, in: Algal culturing techniques, edited by: Andersen, R. A., Academic Press, San Diego, CA, 253-267, 2005.

Martin, A. P.: Phytoplankton patchiness: the role of lateral stirring and mixing, Prog. Oceanogr., 57, 125-174, 2003.

Nittis, K., Lascaratos, A., and Theocharis, A.: Dense water formation in the Aegean Sea: numerical simulations during the Eastern Mediterranean Transient, J. Geophys, Res., 108, PBE 21, 8120, doi:10.1029/2002JC001352, 2003.

POEM group: General circulation of the Eastern Mediterranean, Earth-Science Reviews, 32, 285-309, 1992.

Rio, M., Poulain, P., Pascual, A., Mauri, E., Larnicol, G., and Santoleri, R.:A Mean Dynamic Topography of the Mediterranean Sea computed from altimetric data, in-situ measurements and a general circulation model, J. Mar. Syst., 65, 484-508, doi:10.1016/j.jmarsys.2005.02.006, 2007. 
Rosentraub, Z. and Brennerb, S.: Circulation over the southeastern continentalshelf and slope of the Mediterranean Sea: Direct current measurements, winds, and numerical model simulations, J. Geophy. Res., 112, C11001, doi:10.1029/2006JC003775, 2007.

Rupolo, V., Marullo, S., and Iudicone, D.: Eastern Mediterranean Transient studied with Lagrangian diagnostics applied to a Mediterranean OGCM forced by satellite SST and ECMWF wind stress for the years 1988-1993, J. Geophys. Res., 108, 8121, doi:10.1029/2002JC001636, 2003.

Schlitzer, R.: Ocean Data View, http://odv.awi.de, 2011.

Siokou-Frangou, I., Christaki, U., Mazzocchi, M. G., Montresor, M., Ribera d'Alcalá, M., Vaqué, D., and Zingone, A.: Plankton in the open Mediterranean Sea: a review, Biogeosciences, 7, 15431586, doi:10.5194/bg-7-1543-2010, 2010.

Tanaka, T., Zohary, T., Krom, M. D., Law, C. S., Pitta, P., Psarra, S., Rassoulzadegan, F., Thingstad, T. F., Tselepides, A., Woodward, E. M. S., Flaten, G. A. F., Skjoldal, E. F., and Zodiatis, G.: Microbial community structure and function in the levantine basin of the eastern Mediterranean, Deep-Sea Res., 54, 1721-1743, 2007.
Tanaka, T., Thingstad, T. F., Christaki, U., Colombet, J., CornetBarthaux, V., Courties, C., Grattepanche, J.-D., Lagaria, A., Nedoma, J., Oriol, L., Psarra, S., Pujo-Pay, M., and Van Wambeke, F.: Lack of P-limitation of phytoplankton and heterotrophic prokaryotes in surface waters of three anticyclonic eddies in the stratified Mediterranean Sea, Biogeosciences, 8, 525-538, doi:10.5194/bg-8-525-2011, 2011.

Weinstein, Y., Less, G., Kafri, U., and Herut, B.: Submarine groundwater discharge in the southeastern Mediterranean (Israel), preliminary results, Radioactiv. Environ., 8, 360-372, 2006.

Yacobi, Y., Zohary, T., Kress, N., Hecht, A., Robarts, R. Waiser, M., Wood, A., and Li, W.: Chlorophyll distribution throughout the southeastern Mediterranean in relation to the physical structure of the water mass, J. Mar. Syst., 6, 179-190, doi:10.1016/09247963(94)00028-A, 1995. 